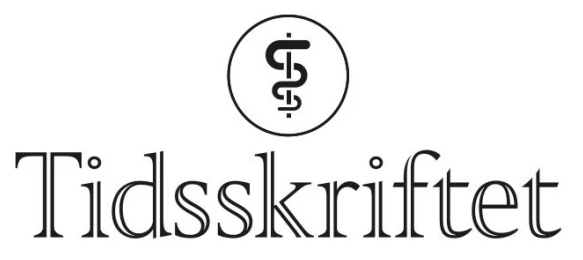

DEN NORSKE LEGEFORENING

\title{
Noskapin og warfarin - en potensielt farlig interaksjon
}

\author{
BREV TIL REDAKTØREN
}

KIRSTEN MYHR

RELIS Øst legemiddelinformasjonssenter

Noskapin er et hostestillende middel som stort sett bare brukes i Skandinavia. Informasjon om stoffets egenskaper er derfor begrenset. Det er reseptfritt, og eventuell interaksjonsrisiko med andre legemidler vil ikke fanges opp på apotek eller hos lege dersom det ikke er nevnt i preparatomtalen.

I 2008 mottok RELIS Øst en bivirkningsmelding der en pasient som bruker warfarin fikk $ø \mathrm{kt} \mathrm{INR}(>8)$ etter å ha begynt med noskapin. I 2009 har vi mottatt ytterligere tre rapporter. Alle tilfellene ble oppdaget ved rutinekontroll hos lege og fikk heldigvis ingen medisinske konsekvenser.

Interaksjon mellom noskapin og warfarin er først nylig beskrevet, og begge publikasjonene er fra Sverige (1, $\underline{\mathbf{2}}$ ). Interaksjonen er ikke beskrevet i internasjonale oppslagsverker (3) eller i preparatomtalen (4). I DRUID og i interaksjonskapitlet i Norsk legemiddelhåndbok er interaksjonen nevnt $(5, \underline{6})$. Årsaken til at interaksjonen er dårlig kjent, kan være at noskapin er lite brukt på verdensbasis. En annen årsak kan være at det er reseptfritt og dersom INRstigningen ikke fører til alvorlig blødning, kan interaksjonen overses. Det kan også skje om pasienten blir innlagt med en blødning og ikke opplyser om inntak av noskapin.

Ved utgangen av 2006 var i alt åtte tilfeller rapportert til det svenske bivirkningsregisteret, ett tilfelle av blødning og sju tilfeller med INR-stigning (1). Scordo og medarbeidere beskrev fire tilfeller av INR-stigning fra et sentralsykehus i Sverige i $2007(\underline{2})$. Dermed er det i alt kjent 11 tilfeller av $ø$ kt INR og ett tilfelle av blødning i Sverige.

Interaksjon mellom warfarin og noskapin er altså ikke særlig godt kjent og er et utmerket eksempel på begrensninger i interaktive elektroniske interaksjonsdatabaser som skal si ifra om interaksjonspotensial for legemidler oppført på resepten. Noskapin er et reseptfritt legemiddel.

Interaksjonen illustrerer dessuten potensialet for alvorlige problemer med preparater som selges uten resept. Det er i tillegg risiko for at interaksjonen ikke vil oppdages ved eventuell sykehusinnleggelse dersom det ikke tas opp en god legemiddelstatus som omfatter reseptfrie legemidler. Informasjon i preparatomtale (4), Felleskatalogtekst og pakningsvedlegg er ikke oppdatert. 
Apotek og leger må informere «Marevan-brukere» om at de må unngå noskapin. Tilfeller av INR-stigning og/eller blødning ved bruk av kombinasjonen meldes som bivirkning til RELIS.

\section{LITTERATUR}

1. Ohlsson S, Holm L, Myrberg O et al. Noscapine may increase the effect of warfarin. Br J Clin Pharmacol 2008; 65: 277-8.

2. Scordo MG, Melhus H, Stjernberg E et al. Warfarin-noscapine interaction: a series of four case reports. Ann Pharmacother 2008; 42: 448-50.

3. Baxter K, red. Stockley"s Drug Interactions. London: Pharmaceutical Press, elektronisk versjon. www.medicinescomplete.com/mc/stockley/current/login.htm? (21.1.2009).

4. Statens legemiddelverk. Preparatomtale (SPC) Noskapin. www.legemiddelverket.no/legemiddelsok (21.1.2009).

5. Spigset O, red. Drug Information Database (DRUID). www.interaksjoner.no/ (7.7.2008).

6. Norsk legemiddelhåndbok for helsepersonell. www.legemiddelhandboka.no/ (21.1.2009).

Publisert: 12. mars 2009. Tidsskr Nor Legeforen. DOI: 10.4045/tidsskr.09.0123

(C) Tidsskrift for Den norske legeforening 2023. Lastet ned fra tidsskriftet.no 26. april 2023. 